\title{
Analysis of Climatic Conditions Effect on Tourism Plants and Flowers of Guilin by Computer
}

\author{
Xianda Bai, Yu Tan \\ Guilin meteorological bureau (Guangxi Guilin, 541001) \\ glbxd@126.com
}

\begin{abstract}
Key words: Computer analysis, Ornamental plant, flowers, climatic condition, tourism impact.
Abstract: To development of Guilin plants and flowers tourism, Guilin tourism plants and flowers has been studied by computer. A lot of date of Guilin climatic change and tourism plants has been study by computer. It is mainly analysis of climate change effected on some main ornamental plants optimal viewing period and the flowers blooming times. Guilin scale plants and flowers for tourism enjoy the sight of mainly are peach blossom, rape flower, lotus, sweet Osmanthus, and ginkgo yellow leaves, tallow red leaves, red maple leaves, Metasequoia, etc. The best viewing time of the ornamental plants and flowers are affected by climate conditions. The temperature and precipitation are the main influence factor, light, humidity and wind also has a certain influence. Reasonable planting, considering both scale and economic benefits, and season, so it is can enjoy the sight of the ornamental flowers and plants in four seasons every year, it will play a good promoting role in Guilin's tourism.
\end{abstract}

\section{Introduction}

Guilin with picturesque scenery, the hole stone beauty, pleasant environment, has become the world know the tourist resort. In recent years, the construction of Guilin tourism experimental area approved by the state, Guilin's tourism has a bright spring. Guilin tourism new attractions and new route was developed and optimized continuously. The ornamental plants and flowers for tourism have been pay attention more and more, GongCheng peach flower festival, Yngshuo one hundred $h a$ of rape of, LiPu mandarin section, Zhemu piece flower, Huixian continuous whole lotus, the Li-river side tallow beach tallow red leaves, Haiyang township, ten thousand acres of ginkgo biloba, and some scattered distribution of red maple, these new attractions in the best viewing season can attract a large number of residents and tourists every day. Especially on weekends, scenic spot is crowded and traffic flies every day. To enjoy the sight of ornamental plants and flowers has become a tourist, particularly of local resident leisure tourism activities. Plants and flowers all has a best ornamental period, it shall be control by climate. Through the study of local ornamental plant climate adaptability, it can provide a scientific basis for arrangement of major tourism activities and for reasonable planting all kinds of ornamental plants, The influence of climate on travel have studied by a lot of scholars, but most is the study of the relationship between climate and comfort [1-2]. Also have some discussions to the climate of crop flowering period, QuJing, Liu Liu [3-5] have done special research of peach bloom prediction; Wang Cunzhen [6] on the climate characteristics of Guilin Osmanthus beginning flowering and forecast analysis; Tang Song [7] summarized and reported Chongqing rape flower visited rape boost the local tourism developed. The characteristics of large scale plants or flowers will attract a lot of guests, plants and flowers view and admire has become popular options by surrounding visitor. Tourism plants and flowers under the influence of climatic conditions, very little research in this area. In this article, through the analysis of these effects by computer, it can provide a scientific reference of planting tourism plant and flower for development tourism economy of Guilin.

\section{Use computer for data processing}

The author collected the Guilin nearly 50 years data of climate change and tourism plants, Using VB computer programming languages, program design, to deal with these data. Mainly for the related 
calculation between them. According to the relevant degree, the good relevant date has been analyses again.

\section{The Guilin of geography and climate}

Mountain range. Guilin is located in the northeast of Guangxi, the north and east is connect with Hunan. Northern mountains mainly are Yuecheng mountains, South mountains, Tianping mountains, The main peak of Yuecheng mountains is Miaoer hill at an altitude of $2142 \mathrm{~m}$, it is the highest peak in south China. Eastern DuPang mountain, leek fragrant-flowered garlic hill, $2001 \mathrm{~m}$ above sea level. In the central mountain, Haiyang treasure Baojie hill, $1936 \mathrm{~m}$ above sea level. It is fixed for bridging ridge in the west and the south, the main hill is Siding mountain, elevation $1247 \mathrm{~m}$, South to north of big Yao mountain along the flows. It is soil mountain in the northern of Guilin city, in the south of Guilin downtown are more KARST geology, Good peak cluster, also its development and butte, has become the world's nature heritage protection center, it is the main component of Guilin landscape. The rivers. The main rivers are Li-river, it is come from Miaoer mountain, from north to south through Guilin city, into the West rivers; Xiang-river, is collected form Miaoer mountain, through Xinan and Quanzhou into Hunan Xiang-river; Louqing-river, from Lingui, south through the Yongfu, then westing into the Liu-river; Guan-river is located between DouPang and Haiyang mountain, northward in Quanzhou to Xiang-iver; In addition there are Xun-river, Cha-river and LiPu river. Distributes the rivers around the city; The Li-river, Zi-river tour, Five rows river, Yulong-river rafting all are tourists love projects. River tourism has become an important part of Guilin landscape tour, reservoir tourism also become short guests often chosen.

Climate of Guilin. Guilin is located in the low latitude area, belongs to subtropical monsoon climate zone, heat is rich, abundant rainfall, sufficient sunlight, in most climate condition is superior. The main meteorological disasters are: low temperature and rain, drought, storm, flood, hail and strong wind, thunderstorms, frost, cold air, etc. Guilin city and counties annual average temperature is $16.2 \sim 19.9^{\circ} \mathrm{C}$, the urban average annual temperature of $18.8^{\circ} \mathrm{C}$, Temperature has obvious seasonal change, four seasons is distinct. Lowest temperature in January, Ziyuan county is $8.4{ }^{\circ} \mathrm{C}$, the highest temperature in July, all extreme maximum temperature $38.3 \sim 40.4{ }^{\circ} \mathrm{C}$. The low temperature days when the daily minimum temperature is lower than $0^{\circ} \mathrm{C}$ in all of Guilin is $2 \sim 11 \mathrm{~d}$, except the northern mountainous area of Ziyuan county is $19 \mathrm{~d}$, The high temperature weather when daily highest temperature is higher than $35.0^{\circ} \mathrm{C}$ is $12 \sim 28 \mathrm{~d}$, in addition to Ziyuan county is $6 \mathrm{~d}$, the county, daily maximum temperature $37.0^{\circ} \mathrm{C}$ high temperature weather, Ziyuan county is $0 \mathrm{~d}$, the rest of the county are $1 \sim 4 \mathrm{~d}$.

Guilin is located in the northeast of Guangxi, the northeast to the southwest is the main channels of Xiang-Gui corridor from that the cold air invasion of Guangxi, the surrounding mountains ups and downs, rivers crisscross, is one of the heavy rain center of Guangxi, the average annual rainfall between 1300 $2000 \mathrm{~mm}$. The precipitation is little in southern four counties, north-central counties are more, Yongfu is one of the most annual precipitation County. But because of Guilin are influenced by monsoon climate, dry and wet seasons is very obvious. From May to July is precipitation peak month. Heavy rains and a few days heavy rain process is the main cause of city flood. It is no rain for ten days to 60 days quite often in the autumn and winter season.

Guilin sunshine times seasonal variation is obvious, the sunshine can reach more than 2000 hours for many years, the juvenile only 1200 hours, for many years and most teenagers are nearly is 800 hours.

Guilin is the high incidence of thunderstorms, the annual average thunderstorms days have 76 days, the maximum is up to more than 100 days.

Guilin's main severe weather is: the low temperature of spring and autumn; In Spring and summer, the storms, floods, hail, thunderstorm winds and thunderstorms are often happened; Autumn and winter drought; Winter cold wind, frost, frozen, etc. Other disasters caused by hail, wind, thunderstorms, etc. are also a certain influence on the local production of workers and peasants. 


\section{Guilin tourism flowers and climate characteristics}

Guilin is located in the temperate zone, is rich in plant species, flowers and plants diversity, Integrat ion scale flowers are: rape, peach blossom, and, cherry blossoms, azalea, osmanthus, hibiscus flowe rs, sunflower, thanks; Into the size of the ornamental plants have tallow and yellow leaves of ginkg o biloba, tallow beach in the fall of the maple leaves, maple red leaves.

Rape flower. Even a piece of rape will make up a yellow sea. Rape flower has grown in all Guilin city, Lingchuan, Yangshuo, Yanshan, Longsheng concentration of rapeseed is most attract tourists. Rape resistance to low temperature, more than $-4{ }^{\circ} \mathrm{C}$ could survive, $10 \sim 15{ }^{\circ} \mathrm{C}$, should be flower. It suitable planted in winter, the spring flowers. Rape is usually open at the end of February to early March, in the middle of March to early April is blooming period, it is basically all drop off in the middle of April. Flowering is generally a week or ten days. Bloom when the suitable temperature is about 22 degrees or so.

Peach, and Plum flowers. Peach, and Plum flowers open in early March to early April at the same time. The colour of Plum flowers are white, the peach blossom colour sort are more, the red give priority to. There are large-scale planting peach in GongCheng west hill township and Lingchuan Haiyang countryside. All hills are red at the peach blossom times, a large number of tourists are attract to watch the peach flowers in March to early April each year, especially GongCheng peach flower festival, has been held for 10 consecutive years, major festivals become the county tourism and investment. Guilin city in the peach blossom, peach blossom river counties scattered distribution of peach trees, have become a good place for citizens have a leisure weekend. Spring temperatures to rise to more than $10^{\circ} \mathrm{C}$, peach flower bud stirring, when the temperature is $12 \sim 14{ }^{\circ} \mathrm{C}$, the peach flower bloomed.

Cherry blossom. Cherry blossoms are mainly concentrated in several park in Guilin city, such as the Western hills, Nanxi park has a cherry blossom, due to different varieties of cherry, March to May can see blooming cherry blossoms, is very popular among the citizens. Above $10{ }^{\circ} \mathrm{C}$ began to sprout, blossom at $12 \sim 15^{\circ} \mathrm{C}$.

Azaleas. Azaleas can call a lot of names, because it grow at all hills, the whole mountain are red flower at spring, also known as azalea. The flowers open in March to May each year. The most varieties had collected form Miaoer hill, due to the mountain is vertical climate differences. Flowering time also varies. Flower color is given priority to with red, pink, red, purple, and very beautiful flowers. Low temperature resistant, not fallen leaves in the winter, spring flowering, when the temperature in the $12 \sim 15{ }^{\circ} \mathrm{C}$ concentrated flowering.

Osmanthus. Guilin named by the city of Osmanthus, also has become the Guilin Osmanthus flower, before and after the annual Mid-Autumn festival, the whole city the Osmanthus fragrance, the ocean of Guilin became sweet. Autumn flowering Osmanthus relationship with cold and rain is very big, affected by the cold air temperature is less than $22^{\circ} \mathrm{C}$, after a rainfall, temperature rise, dry in the sun, the Osmanthus began to blossom.

Lotus. In the center with southern suburbs and Huixian wetland, farmers have the habit of planting lotus root. At early summer, lotus in full bloom, pink flowers, green lotus, swaying leaves, visitors take a small bamboo raft, through the continuous lotus pond, fairyland feeling makes visitors revel in lotus. It flowers in June to September, daily morning on both off. It fruits at August to October.

Ornamental plants. There are many ornamental plants in Guilin, Yangshuo around the big banyan tree, big camphor tree etc. all can attract a lot of tourists. However, Lingchuan Haiyang mountain ginkgo, the Li-river side of Chinese tallow tree, QiXing Road and Xifeng road of city downtown red maple, golden yellow ginkgo leafs of biloba. Xingan, Lingchuan ginkgo viewing has become an important scenic spot in Guilin. Nearly two years, Chinese tallow tree at the edge of the Li-river, because the tallow is extremely strong vitality in the sand, the leaves turn red when the winter, river, beach, piece maple leaf is also very beautiful scenery. A family, a bunch of friends, driving to the beach, picnics, chat, the sunshine, playing games, what a leisure. Winter, the temperature drops to below $20^{\circ} \mathrm{C}$, the leaves of these plants began to change color, when the temperature less than $12{ }^{\circ} \mathrm{C}$, the leaves begin to fall off. 


\section{Climate change impact on flowers}

Flowering ornamental plant, the flowers, it is affected by the climate, growth and survival depends on temperature, precipitation, illumination. It bloom sooner or later, the relationship with the tempe rature is also very big. Ornamental plant phase difference is very big to the requirement of climate c onditions, early spring flowering plants (peach) is affected by the effective accumulated temperatu re; Osmanthus flowering date of precipitation before and after before the Mid-Autumn festival, the influence of the cooling and warming process change in the weather; Ginkgo leaf colour plants are affected by the cold air.

Spring flower. These class Including peach, plum, pear, cherry blossom, winter jasmine, rape, aza leas, etc., are all the spring flowers, QuJing [4] analysis found that the temperature of the peach blos som condition is that the daily average temperature $10^{\circ} \mathrm{C}$ or more stable, and the effective accumul ated temperature $10^{\circ} \mathrm{C}$ or higher is $188^{\circ} \mathrm{C}$. . And similar to peach, pear, cherry blossoms, azalea, th ey belong to the fallen leaves in winter, the spring flowering plants.

Osmanthus class. Lijun analysis found [7], Osmanthus flowers, is close relations to the early low-temperature. Baixianda[8] found, such as Osmanthus flower to undergo early low temperature, precipitation, and warm clear up 2-3 days, then flowering.

Ginkgo. Autumn to winter season, often influenced by cold air, the temperature drop, many plants will be physiological changed because of the temperature and other meteorological factors effected. The leave of some plants contains some natural pigment, such as chlorophyll, lutein, anthocyanin and carotene. Because of these pigment content and proportion of the leaf color changes caused by different. Spring and summer season, high temperature, moisture content, is the main growth period, plant chlorophyll content is bigger, and lutein, far below the chlorophyll carotene content, leaf chlorophyll, the green. Due to the synthesis of chlorophyll needs strong light and high temperature, in the fall, with the drop of temperature, light, chlorophyll synthesis, and chlorophyll is not stable, see light easy decomposition, decomposition of chlorophyll and not get added. So the chlorophyll in leaf ratio is reduced, and lutein and carotene is relatively stable, not easily influenced by the outside world. Therefore, blade is displayed. In autumn winter season, as the anthocyanin content of chlorophyll gradually decreased with increasing, some plants with mesophyll contains acid. Anthocyanins is a kind of volatile organic compounds, itself has no color, turn red when it encounters the acid. By this way, the leaves become red.

\section{Take advantage of climate, a reasonable planning flowers plant cultivation}

Guilin to clear all the year round, there are many different kinds of plants and make full use of the advantage of local climate, select plants with high ornamental value, scale of planting, formation cha racteristics, create a new tourist attraction. Tang Song [9], the study found piece plant rape, you can to the local tourism plays very important role. Guilin tourism in recent years, the practice also prove $\mathrm{d}$ that the citizens are short swim more and more hot, the weekend, the family, several family memb ers, a group of friends, find a good scenery, good air leisure, a good relax, has become a new fashion. "Spring flowers, summer is cool, color of the fruit of autumn and winter" has become the guiding $\mathrm{p}$ rinciples of guilin tourism agriculture development.

Spring flowers Guilin now has been formed mainly GongCheng, ling chuan peach garden, peach blossom river peach also rows into downtown; Rape in many parts of the city have grown; It was th e season of azalea blossoms in spring, azaleas Bunsen easily generated, can in some appropriate pla nting on barren hills, making it a sea of flowers.

Summer cool hot summer, people at the same time of leisure travel, hope to get a cool, forest bot anical garden, is the ideal place. By planting some flowers, and beautify the plant, make some barre $\mathrm{n}$ hills, barren hills gradually become people travel to the summer paradise. A lot of flowers suitabl e for summer, lotus, chrysanthemum, smartweed flowers, bougainvillea, cotton rose, the four season s of cassia, honeysuckle, oleander, crape myrtle, summer is cool, and give attention to two or moret hings appropriate is given priority to with woody plants. 
The autumn fruit Guilin is filled with fruitful autumn, orange, pomelo, persimmon, chestnut, corn, sweet potatoes, fructus momordicae, grapes, watermelon, cantaloupe, strawberries, etc., visitors can pick fruit variety, fruit and vegetable planting area has a lot of, to develop appropriate for self-help tourists need fruits and vegetables.

Color guilin winter winter, snow is not much, but plants rich colors, especially before the winter season, ginkgo leaves other delectable, tallow, maple, maple, pink, red, CengLinJinRan, sea towns hip red and yellow leaves of ginkgo biloba, tallow beach watch tourism has become a hot tourist gui lin winter project.

View combined with economic benefit Encourage farmers to develop not only has direct economi c benefit and has ornamental value of the crop, from the spectator activity to obtain more economic benefits. Such as rape, fruits and vegetables; For some not suitable for planting fruits and vegetables of wasteland (mountain), can be conscious cultivation of ornamental plants, such as ginkgo biloba, maple, tallow, etc.. It is needed to develop its tourism value.

Development measures Encourage conditional farmers planting watermelon, cantaloupe, strawbe rries, corn, persimmon, grapefruit, oranges, grapes and so on, open to the tourists harvest, increase $t$ ourism sites, and increase farmers income.

\section{Summary}

(1) A lot of plants and flowers for people to watch, the reasonable scale of planting, certainly can be come the new places for citizens leisure vacation.

(2) More into the size of the guilin tourism flowers are: rape, he flowers, peach blossom, and, chrys anthemum, lotus, sweet osmanthus; Compare with people like the ornamental plants have: gingko, maple, metasequoia, tallow; Suitable for rural tour of fruits and vegetables are: watermelon, cantalo upe, strawberries, corn, persimmon, grapefruit, oranges, grapes.

(3) Tourism ornamental plants is affected by climate, rational utilization of local climate resources, scale development related plants, can play a positive role for guilin tourism. Use a variety of plants to climate adaptability, scientific arrangement, can realize most of the time all the year round all can see the beauty of the nature landscape.

(4) Computer can handle a huge number of meteorological data, it can provides a great help for anal ysis of the impact of climate change and tourism plant .

\section{References}

[1] xiao-li ye, WeiPeiQiong QinRuQian, guangxi bama county nearly 10 years traveling comfort analysis [J], meteorological research and application, 2012.33 (suppl) : 84-89.

[2] liu mei, bo, human comfort research status and development prospect [J], meteorological science and technology, 2002, 30 (1) : 11-15.

[3] Mary, gemany, nearly 20 years the influence of climate warming on Beijing seasonal tourism - in the case of Beijing botanical garden peach flower festival [J], earth science, 2006, 21 (3) : 313-319.

[4] QuJing, sightseeing peach coated prediction [J], shaanxi meteorological, 2010, (3) : 19-21.

[5] Liu Liu, a loyal, peach blossom type sooner or later in the winter climate characteristics of flowering and prediction [J], meteorological, 2006, 32 (1) : 113-116.

[6] Wang Cunzhen Tang Guangtian, xian-da bai, osmanthus flowering meteorological forecast research [J], China agriculture bulletin, 2014, 30 (22) : 74-78.

[7] li, qiu-zhen Yang, of silver and Yang Kangmin GuiChu flowering conditions [J], journal of plant ecology, 2006, 30 (3) : 421-425. 
[8] Xianda Bai,Analysis on Agricultural Meteorological Condition of Osmanthus Blooming [J],Agricultural Science \& Technology,2014,15(9):1612-1616.

[9] Tang Song, in March dish of flowers - model.flood-control of rape pull big tourism [J], chongqing and the world: the second half, 2012, (3) : 60-61. 